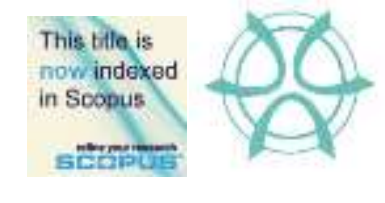

PLANNING MALAYSIA:

Journal of the Malaysian Institute of Planners

Volume XIII (2015), Page 101 - 122

\title{
CARBON SEQUESTRATION THROUGH URBAN GREEN RESERVE AND OPEN SPACE
}

\author{
Alamah Misni ${ }^{1}$, Sakurah Jamaluddin² \& Siti Mazwin Kamaruddin³ \\ ${ }^{1,2 \& 3}$ Faculty of Architecture, Planning and Surveying \\ UNIVERSITI TEKNOLOGI MARA MALAYSIA
}

\begin{abstract}
The world is experiencing rapid development and urbanisation of urban areas that cause an increase in the carbon emission which contributes to greenhouse gasses and global warming. The environment has been declining for the past few years while extreme weather has impacted some urban areas in Malaysia. In 2009, the Malaysian government pledged to achieve up to $40 \%$ voluntary reduction in carbon emission intensity by 2020 . Now it is time to move forward by proposing the green and low-carbon way to offset carbon emission from both planning and landscaping perspectives. This research demonstrates how urban green reserves, being a vital land use component in the urban area, is effective in carbon sequestration to absorb and store carbon emission for an extended term. Through the natural process of photosynthesis, mature trees planted in urban green reserve and open space can act as a carbon sink. This research computes the volume of carbon sequestration of trees planted in urban green reserve and the open space within the study area. Through this study, the accurate allometric relationship for the total above-ground biomass with the tree diameter and height was developed to estimate the rate of carbon sequestration in Pasir Gudang. The results based on mature trees inventory revealed that the total amount of carbon sequestration contributed by both urban green reserve and open space were 2,238.183 tons of carbon per year. Within the design parameters of the case study area, the total contribution of carbon reduction was merely $3.15 \%$ per year compared to the target of $10 \%$ carbon reduction via carbon sequestration. The total balance of carbon reduction that needs to be offset via carbon sequestration is $6.85 \%$. Therefore, there is a need to provide smart planning and consolidating of low carbon initiatives to increase the contribution of carbon sequestration for a healthier environment in the urban area.
\end{abstract}

Keywords: Carbon emission, carbon sequestration, urban green reserve, and open space.

${ }^{1}$ Senior Lecturer, FSPU,UiTM E-mail:alama884@ salam.uitm.edu.my 
Alamah Misni, Sakurah Jamaluddin, \& Siti Mazwin Kamaruddin

Carbon Sequestration Through Urban Green Reserve and Open Space

\section{INTRODUCTION}

The world has been discussing low carbon technology since a long time ago, but only in 2009, most countries in the world have formally raised this issue comprehensively. The prime minister of Malaysia has mentioned in 15th United Nations Framework Convention on Climate Change in Copenhagen that "Malaysia has committed to reduce the carbon dioxide intensity to the GDP by 40\% GDP per capita by 2020 as compared to 2005 levels; conditional upon transfer of technology and finance for developing nations" (COP15, 2009). This order has been strongly impacted by the decision-makers and stakeholders who are involved in the development. The impact of climate change is happening around the world including Malaysia. Therefore, we have been advised by the United Nation as well as a developed nation to move forward efficiently towards low carbon technology to minimize carbon emission and maximize carbon sequestration. The focus area is the urban area where the concentration of development is the most.

Global warming and climate change that contributed to carbon emission are the most crucial issue (EIA, 2006). For the past five years since the declaration of carbon footprint reduction in Malaysia, Malaysia has produced several methodologies to obtain carbon reduction (KeTTHA, 2014). However, this research will view from different angles of carbon reduction through carbon sequestration reserve between the existing urban areas to ensure the maximizing of carbon absorption and carbon reduction. This research will take part by concentrating the green reserve and open space in a developed area. As the urban area has been found to be the place of higher generation of carbon emission (Dhakal, 2009; Misni and Allan, 2010: Misni, 2012), therefore urban areas, particularly existing urban areas are the most significant area to be studied. Green reserve in an existing urban area is an important area and cannot be used by other usage or activities except for green purposes only (USDA, 2014). This reserve should be planned as a place that will contribute higher carbon sequestration and helps to reduce the carbon emission for the scenario of urbanization process in Malaysia. This study applies the National Green Technology Policy with the release of greenhouse gas (GHG) low or zero in any development area in Malaysia (KeTTHA, 2014). In addition, this study provides the insights into the role of urban green areas for decision-makers and the public to make a better management plans to protect and maintain these areas.

\section{GREENHOUSE GASES}

Atmospheric carbon is the most abundant anthropogenic gases among other gases in the air. According to the greenhouse gas theory, other gases contain in the atmosphere are methane, nitrous oxide, and fluorinated gases. All these gases that trap heat in the atmosphere are called greenhouse gases in which it contributes pollution to the atmosphere and causes global warming. The greenhouse effect is 
PLANNING MALAYSIA

Journal of the Malaysia Institute of Planners (2015)

not a bad thing by itself because it allows Earth to stay warm enough for living things to survive. The greenhouse effect is a complicated heat circle and process. When the sunrays hit the surface of earth and earth's atmosphere, approximately $70 \%$ of the energy or heat stays on the planet which is absorbed by several components of earth such as land, oceans, and plants (NASA, 2014). The other $30 \%$ is reflected into space by clouds, snow fields, and other reflective surfaces. However, even the $70 \%$ of the energy that gets through does not stay on earth forever due to ecological and biological process. The Earth's oceans and land masses eventually radiate the heat back out and some of the heat make it into space (EPA, 2014).

The rest of it ends up getting absorbed when it hits certain things in the atmosphere such as carbon dioxide and water vapour. After these earthy components in our atmosphere absorb the heat radiated from the sun, they emit energy that also in the form of heat. The heat that does not make it out of the earth's atmosphere keeps the planet warmer than the outer space because more energy is coming in through the atmosphere than the energy that goes out. This is the right part of the greenhouse effect that keeps the Earth warm. However, the greenhouse effect has increased continuously due to the contribution from other heat agents such as industry activities, transportation system, urban development, tree cutting, deforestation, and other activities. Through the process of greenhouse effect, the atmosphere traps some of the solar radiation as a greenhouse, thus increases the planet's temperature, and eventually causes global warming.

\section{CLIMATE CHANGE}

The Earth's climate has changed throughout history. Most of these climate changes are attributed to subtle variations in the Earth's orbit and the change in the amount of solar energy that the planet receives. The heat-trapping, nature of carbon dioxide, and other gases have been demonstrated in the mid-19th century (NASA, 2014). Globally, the average surface air temperature has increased $0.5^{\circ} \mathrm{C}$ in the 20th century. It is estimated that the global average air temperature would further increase by $1.5-4.5^{\circ} \mathrm{C}$ by the year 2100 (Houghton et al., 1996; Misni, 2012). The increase in the level of greenhouse gases will cause the Earth to warm in response. The increased of atmospheric carbon dioxide is attributed mostly to fossil fuel combustion (about 80-85\%) (Hamburg et al., 1997). According to Olivier et al. (2005), carbon dioxide is dominant in greenhouse gases, which accounts approximately three-quarters of the total emissions of greenhouse gases. Atmospheric carbon is estimated to increase approximately 2,600 million metric tons annually (Sedjo, 1989). Urban areas are already warmer than surrounding rural environments due to high proportion of impervious surfaces and high level of fossil fuel combustion (Weng and Yang, 2006). Thus, the impacts of climate change on saturated and developed urban areas in the city centre are worst. 
Alamah Misni, Sakurah Jamaluddin, \& Siti Mazwin Kamaruddin

Carbon Sequestration Through Urban Green Reserve and Open Space

\section{CARBON SEQUESTRATION}

The main purpose of carbon sequestration is to absorb and store the carbon from the atmosphere in trees for a very long time. Atmospheric carbon is the most abundant anthropogenic gases among other gases in the air. Carbon sequestration is simply a process of keeping the carbon out of the atmosphere, in which according to the most scientific theory, it contributes to the greenhouse effect. Terrestrial carbon sequestration is the most significant method to keep the carbon out of the atmosphere. Storing the carbon at the earth's surface is considered as a direct intervention in the natural environment (EPA, 2014). Terrestrial sequestration occurs in forests, crops, soils, subsoil, and bedrock in which it naturally stores carbon but release it again as carbon when people cut down forests, harvest crops, and disturb soils. This method can be defined as the permanent storage of greenhouse gases, therefore they do not contribute to the greenhouse effect.

Urban green areas including urban forests, open spaces, and urban green reserves can play an important role in mitigating the impacts of climate change as a sink for carbon dioxide in urban areas. Urban trees can transform the carbon dioxide into above and below-ground biomass through photosynthesis (Nowak et al., 2013). The process called carbon sequestration stores carbon in the form of stems, branches, or roots (Nowak and Crane, 2002). Urban green area's soils also store a large amount of organic carbon before it releases it into the atmosphere. Quantification of carbon sequestration by urban green areas can be used to assess the actual and potential role of urban trees in reducing atmospheric carbon dioxide (Nowak and Crane, 2002).

\section{CARBON SEQUESTRATION BY TREES}

This study will focus on carbon sequestration by trees. One of the methods is terrestrial carbon sequestration which is performed in order to achieve some target of carbon reduction in urban areas. Unwin and Kriedemann (2000) have generated the model of tree maturity that can be adapted for preliminary accounting of carbon content by a tree. Generally, the maximum growth rate is usually gained early in the life of newly planted trees which soon after the canopy closure. The maximum carbon sequestration gained by every tree is 250 tons per year. This is referring to the national sequestration of carbon stored in a continuous cycle of 1 hectare of annual crop establishment with a 35-year rotation. Trees are capable of efficient sequestration and storage of atmospheric carbon in above-ground and below-ground biomass through photosynthesis process and tree growth.

Carbon sequestration analysis in this study is emphasized on the tree biomass and the carbon content estimation which are significant for carbon reduction in urban areas. From a planning point of view, the estimation of tree biomass is necessary to estimate the percentage of carbon reduction in the 
PLANNING MALAYSIA

Journal of the Malaysia Institute of Planners (2015)

atmosphere in order to reduce the urban heat due to the higher carbon content contributed by human activities and urban development. The rate of carbon sequestration depends on the growth characteristics of the tree species, the conditions for growth (i.e. where the tree is planted), and the density of the tree's wood/trunk/stem (i.e. its biomass). The greatest rate is during the younger stages of tree growth, between 20 and 50 years (DOE, 1998). Researchers can roughly estimate the amount of carbon sequestered in a tree, and divided by the tree's age, a yearly sequestration rate will be obtained. In line with Kyoto Protocol (UNFCC, 2011), as an Intergovernmental Panel on Climate Change, the strategic planning shall be oriented to the renewable energy that can reduce carbon generation and tree biomass that absorbs carbon through zero energy. There are several studies showed the contribution of carbon capture through carbon sequestration. Most of the research concluded that the percentage of carbon that can be absorbed via tree planting is between 5\% and 10\% (Bellassen and Sebastiaan, 2014; UNEP, 2014). For the purpose of this research and looking at the existing and developed urban area of Pasir Gudang as a case study, the targeted percentage is $10 \%$ based on Low Carbon Society (LCS) Blueprint by Iskandar Regional Development Authority (IRDA, 2012). The tree biomass of urban green reserve for the case study area is estimated using an equation developed by Kato et al. (1978).

However, for the purpose of this study, concentration will be given to the above-ground biomass with supporting information from tree inventory and land use survey. The ideal rate of carbon sequestration usually occurs in mature trees and continues to store carbon in a significant amount. It will be based on the tree diameter, tree height, tree healthiness, and other relevant factors. Carbon is absorbed by tree foliage and is stored as carbon organic compounds in woody tissues in a tree trunk, branches, as well as foliage. This absorption by carbon sequestration offers a significant carbon offset in the atmosphere.

\section{METHODOLOGY}

Primary data were collected via tree inventory, observation, and land use survey. The analysis involved identifying the existing land use pattern, the trend of current activity, committed built-up analysis, the tree species planted in the urban green spaces and open space, tree characteristics, and other relevant analysis. The calculation of carbon sequestration can be executed due to some limitations and availability of basic data required to represent the local situation. The analysis process was continued with benchmarking analysis. The benchmarking included the figures of the average amount of tree planted in one hectare land of open space in urban areas and carbon footprint for every single person per year. Another important benchmark was to determine the target of carbon sequestration in Malaysian practice. The benchmarking analysis was done to identify the best practise figure and situation to be adopted in the calculation for current carbon sequestration. 
Alamah Misni, Sakurah Jamaluddin, \& Siti Mazwin Kamaruddin

Carbon Sequestration Through Urban Green Reserve and Open Space

\section{Case Study Area}

Pasir Gudang has a significant role in carbon emission due to the heavy and special industrial activities such as petrochemical and oleochemical, electrical and electronic, metal, plastic, chemical, and food. Pasir Gudang is an industrial and a port town located $35 \mathrm{~km}$ east of Johor Bahru in Malaysia with 110,000 populations. Pasir Gudang is the biggest industrial zone in the southern part of Johor and located in the fastest growing economic region of Iskandar Malaysia. The industry is the main land use pattern, containing almost $50 \%$ of the overall land use of the whole central business district (CBD) in Pasir Gudang district (Figure 1). Currently, the urban forests and open spaces located in Pasir Gudang are being reduced gradually to become developed areas, and the environmental effects of reducing trees in the industrial city's environment of Pasir Gudang have not been studied.

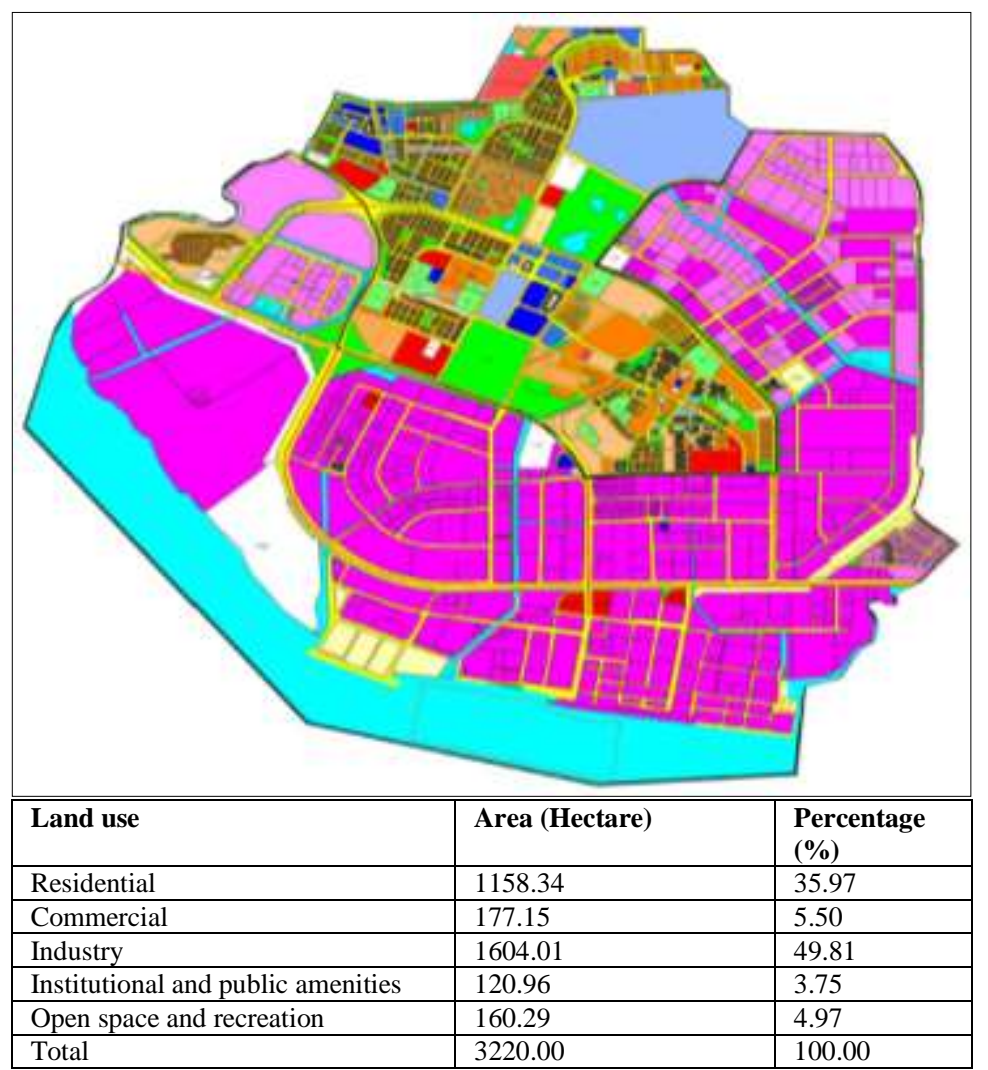

Figure 1. Land use map of Central Business District (CBD) in Pasir Gudang. (Source: Pasir Gudang Local Authority, 2008) 
PLANNING MALAYSIA

Journal of the Malaysia Institute of Planners (2015)

Actions need to be planned to reduce the carbon emission and greenhouse gases in order to gain low carbon development and to support the sustainability of the area. Thus, to explore the carbon sequestration potential of trees in the green reserves in an open space, this study chose the open space located within the CBD with a $500 \mathrm{~m}$ radius of green reserve. This open space has been there since 1990 and is one of the popular open spaces in Pasir Gudang. The surrounding land use of the open space within the stated radius consists of industrial lots, a proposed sports complex, and several residential areas with an estimated population of 10,000 .

\section{Carbon Sequestration Calculation}

\section{Urban Green Reserve}

The urban green reserve is a space for tree planting for the purpose of greening the urban area and generates the corridor of carbon sequestration and carbon sink in the development area. The urban green reserve includes a buffer zone between the road and other land use, a reserve for utility activity, a reserve for maintenance, and buffer zones for industrial activities (Figure 2). This reserve is the limited space in the urban areas and needs to be utilized as an agent of carbon sequestration for the urban areas. For an individual tree located in an urban green reserve, carbon sequestered was quantified using Kato's (1978) formula (Kato, 2011). The total biomass of a tree including the above-ground components (Kueh et al., 2013; EPA, 2014) was determined as follows:

i. The stem biomass was related to the product of the square of diameter breast height (dbh) and tree height.

ii. The branch biomass was the weight of branch estimated from the equation.

iii. The leaf biomass was related to the stem weight estimated from the equation.

iv. The total biomass was the summation of the stem, branch, and leaf biomasses.

v. The amount of carbon sequestration per tree per year.

The calculation was only counted for healthy tree species that can be identified through tree inventory. By using Kato's (1978) formula, there were five criteria needed to generate the amount of carbon sequestration for every tree in the case study area. The tree criteria were species, age, trunk diameter, height, and general condition. 
Alamah Misni, Sakurah Jamaluddin, \& Siti Mazwin Kamaruddin

Carbon Sequestration Through Urban Green Reserve and Open Space

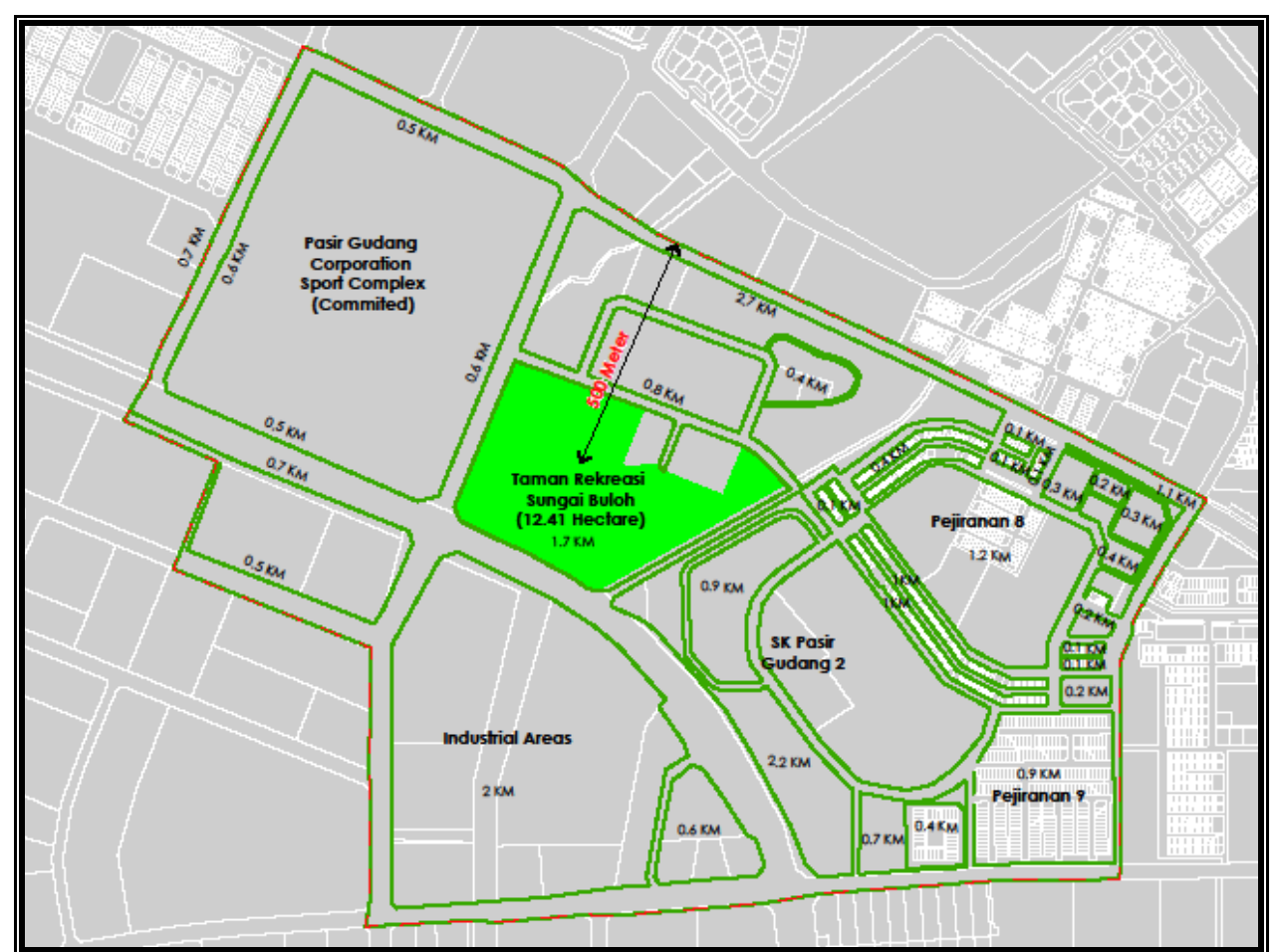

Figure 2. Location of urban green reserve and open space in the case study area in Pasir Gudang $\left(1^{\circ} \mathrm{N}\right.$ Latitude, $103^{\circ}$ Longitude, and average elevation of $\left.30 \mathrm{~m}\right)$

\section{Open Space}

Open space is a place designed to be an area for recreational, sports activities, social activities, and other activities relevant to community recreation. Based on the Act 172, Act Town and Country Planning Act 1976, open space means "any land, whether enclosed or not which is laid out or reserved for setting out wholly or partly as a public garden, park, sports and recreation ground, pleasure ground, walk or as a public place". Open space needs to be provided by every planned urban area based on the hierarchy of open spaces. The requirement of an open space is $10 \%$ of the development area and it shall be handed to the local authority upon completion of the development with completed tree planting and beautification as stated in the planning approval.

For the calculation of carbon sequestration in an open space, another method was used and it was not as detailed as the urban green reserve. According to Myers and Goreau (1991), the formula of carbon sequestration in an open space can be defined by the sum of overall number of biomass per plot or per hectare. Basically, the total carbon sequestration (per ton per year) is the area of the open space (hectare) times the benchmark of how many tons sequestrated per hectare per year (250 tons carbon per hectare per year). Then, the amount is divided by 
PLANNING MALAYSIA

Journal of the Malaysia Institute of Planners (2015)

the above-ground mass per hectare per year. The figure obtained through this calculation was the final amount of carbon sequestration per year for the whole area of the open space. The location of centralized $10 \%$ of the open space in urban areas of Pasir Gudang is mapped in Figure 1.

\section{Tree Characteristic}

Tree inventory of tree species was one of the vital methods in data collection process in this research. The key factor of conducting tree inventory was to identify the characteristics of current trees that have been planted in the urban areas of Pasir Gudang. The tree characteristics included tree trunk diameter, tree height, tree species, the healthiness of the tree, and estimated tree age. All these data play a significant role in calculating the carbon sequestration per year for every tree species to portray the actual contribution of carbon absorption through tree planting, especially for existing and old urban area like Pasir Gudang which has limited space to plant new trees.

Referring to the data tabulated in Table 1, the overall diameter of the tree species in Pasir Gudang was between 8 Dbh and 38 Dbh. This can be measured by a special measurement tape called DBH tape, and this tape was used to identify the diameter of the tree trunk. The height of the trees was measured from the bottom of the tree or at the ground surface level to the highest point of the tree, it can be the leaf or the tree branch. It was measured by using the instruments or tools called clinometer and measurement tape. The data collected showed a huge range of tree trunk diameter and the main reason for this situation is the gradual tree replacement for unhealthy or dead trees. Generally, most of the trees were planted about 10 to 20 years ago during the construction stage of development and continuously replaced during maintenance process by the local authority. Among all tree species planted in Pasir Gudang, three biggest tree species were found in Pasir Gudang during the inventory. These were Khaya senegalensis, Alstonia angustiloba and Pterocarpus indicus which have been planted along the road reserve (Figure 3).

Generally, most of the tree species that have been planted in the urban area of Pasir Gudang were from urban tree species and only a few were from forest tree species. Most probably, during the plantation of trees along the urban green reserve in the early $80 \mathrm{~s}$ and $90 \mathrm{~s}$, urban tree species were promoted due to the fast growing and beauty factors. However, in line with low carbon lifestyle, forest tree is currently the most significant tree species due to the low maintenance, fast growing in cluster planting, easy to maintain after maturing, high survival rate, and greater carbon sequestration. Theoretically, forest tree contributes high carbon sequestration due to the high number of branches, higher stem, and the taproot character possessed (a straight tapering root growing vertically downward and forming the centre from which subsidiary rootlets spring). 
Alamah Misni, Sakurah Jamaluddin, \& Siti Mazwin Kamaruddin

Carbon Sequestration Through Urban Green Reserve and Open Space

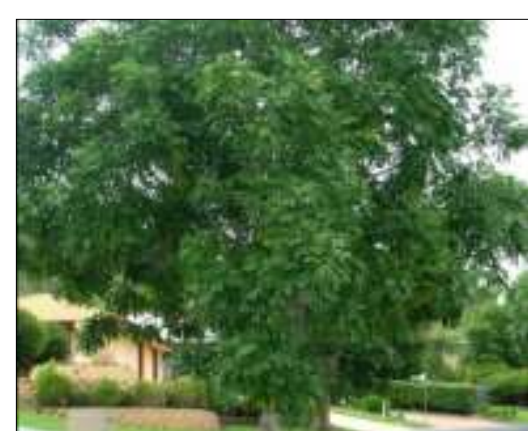

Khaya senegalensis (Khaya)

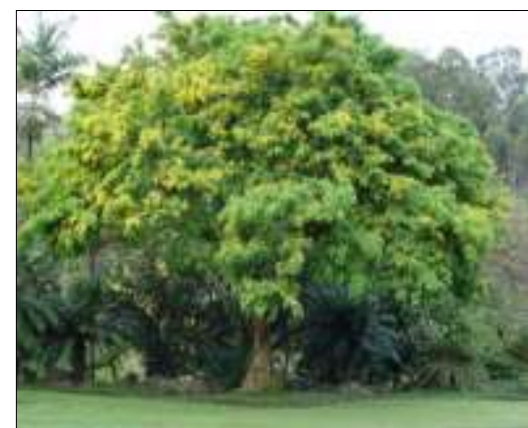

Pterocarpus indicus (Angsana)

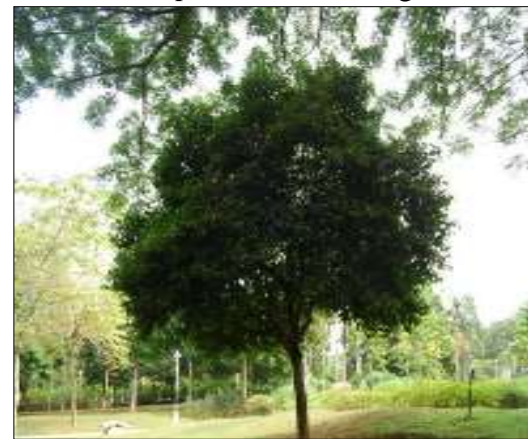

Mimusops elengi (Tanjung)

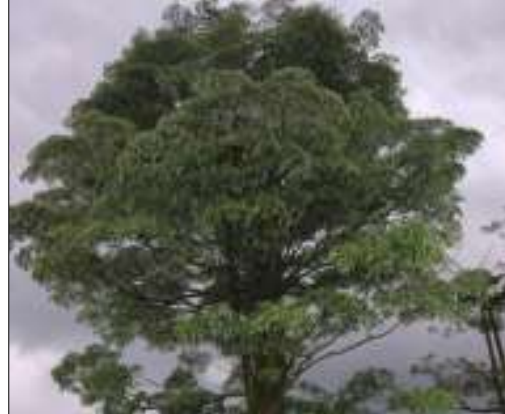

Alstonia angustiloba (Pulai)

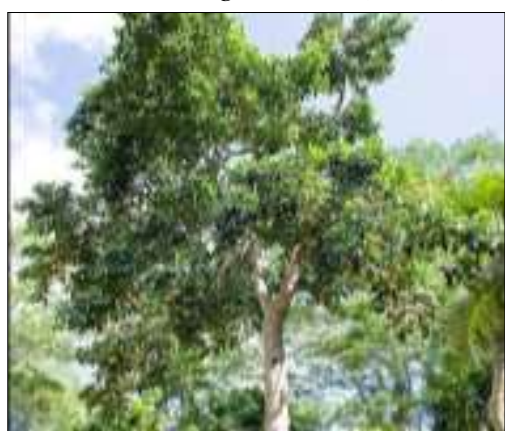

Sandoricum koetjape (Sentul)

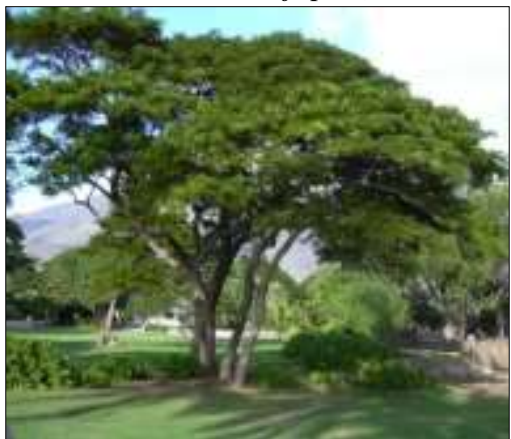

Samanea saman (Hujan-hujan)

Figure 3: Tree species that have highest carbon sequestration in Pasir Gudang 
PLANNING MALAYSIA

Journal of the Malaysia Institute of Planners (2015)

Table 1: Tree characteristic at urban green reserve

\begin{tabular}{lrrr}
\hline Tree Species & $\begin{array}{r}\text { Diameter } \\
\text { Class } \\
(\mathrm{cm})\end{array}$ & $\begin{array}{r}\text { Height } \\
(\mathrm{m})\end{array}$ & $\begin{array}{r}\text { Numbers } \\
\text { of Tree }\end{array}$ \\
& $9-17.5$ & $12-22$ & 35 \\
\hline Hevea brasiliensis (Getah) & 10 & 15 & 1 \\
Dyera costulata (Jelutong) & $14-38$ & $18-21$ & 16 \\
Khaya senegalensis (Khaya) & $8-14$ & $9-13$ & 29 \\
Syzygium grande (Jambu Laut) & $11-26$ & $11-22$ & 47 \\
Alstonia angustiloba (Pulai) & $8-15$ & $7-14$ & 22 \\
Peltophorum pterocarpum (Yellow Flame) & $8.5-12.5$ & $9-12.5$ & 10 \\
Pongamia pinnata (Mempari) & $9-22$ & $7-11$ & 7 \\
Mimusops elengi (Tanjung) & $8.5-9$ & $7-12$ & 2 \\
Garcinia mangostana (Manggis) & 12.5 & 13 & 1 \\
Forest Species (Kandis) & 8.5 & 6 & 1 \\
Dalbergia oliveri (Tamalan Tree) & $9-13.5$ & $9-10$ & 2 \\
Fagraea fragrans (Tembusu) & $8-10$ & $9-17.5$ & 17 \\
Hopea odorata (Merawan Siput Jantan) & $11-21$ & $13-16$ & 2 \\
Sandoricum koetjape (Sentul) & $12-20$ & $8-11$ & 16 \\
Samanea saman (Hujan-hujan) & $8-11$ & $9-15$ & 9 \\
Syzygium polyanthum (Salam) & 13 & 7 & 1 \\
Delonix regia (Semarak Api) & $11-17$ & $8-10$ & 4 \\
Cinnamomum iners (Kayu Manis) & $16-24$ & $9-14$ & 28 \\
Pterocarpus indicus (Angsana) & & & 250 \\
\hline Total & & &
\end{tabular}

\section{RESULTS AND DISCUSSION}

\section{Carbon Sequestration of Urban Green Reserve}

Generally, the types of tree in the urban green reserve of Pasir Gudang were dominated by local trees that have been planted more than 10 years and this morphology is in line with the maturity of the urban area which started more than 20 years ago. Several tree species synonym to Pasir Gudang can be found mostly at the urban green reserve for instance Pterocarpus indicus, Alstonia angustiloba, Syzygium grande, and Hevea brasiliensis. All these tree species have similar characteristics including low maintenance, high survival rate, and sustainable in various types of weather condition. This is also the main reason for the local authority to choose this tree species for landscaping purposes at the urban green reserve.

Based on the tree inventory, 250 units of main tree have been planted along the urban green reserve in the case study area. Alstonia angustiloba or known as Pulai is the type of tree that is mostly planted along the urban green reserve, and there are 47 units. This species has sequestrated 161,329 carbons per year, an 
Alamah Misni, Sakurah Jamaluddin, \& Siti Mazwin Kamaruddin

Carbon Sequestration Through Urban Green Reserve and Open Space

average of $3,433 \mathrm{~kg}$ carbon per tree per year. Based on the calculation, this tree recorded the highest carbon sequestration compared to other tree species. The main reason for this finding is due to the structure of the tree recorded during the tree inventory which can be considered as one of the significant main tree species with a diameter of 11-26 Dbh and a height of $11-22 \mathrm{~m}$. These two factors (diameter and height) technically contribute to the higher rates of carbon sink. Table 1 lists the tree characteristics and Table 2 shows the total above-ground biomass of the tree based on the types of tree species, diameter, and height of the tree.

However, from the data tabulated and the analysis done, the tree species that contributed the highest carbon sequestration in the case study area was Khaya senegalensis with the local name of Khaya. The average carbon sequester rate of this tree was $4,507 \mathrm{~kg}$ carbon per tree per year which was slightly higher than Alstonia angustiloba with a difference of $1,074 \mathrm{~kg}$ carbon per tree per year. 16 units of Khaya senegalensis species have been planted at the urban green reserve and contributed about $72,119 \mathrm{~kg}$ carbons per year. Other tree species that have contributed higher carbon sequestration based on the number of trees in the case study area were Pterocarpus indicus (Angsana) with 78,538kg carbon per year, Hevea brasiliensis (Getah) with 55,850kg carbon per year, Syzygium grande (Jambu Laut) with 32,740kg carbon per tree, Peltophorum pterocarpum (Yellow Flame) with 18,823kg carbon per year, and Samanea saman (Hujan-hujan) with $18,004 \mathrm{~kg}$ carbon per year.

250 number of trees have been identified as mature trees and to be calculated the carbon sequestration in Pasir Gudang urban area. Basically, every tree generates a different amount of carbon sequestration based on the tree characteristics including tree diameter, tree height, and tree health. Based on the tree inventory, the total amount of carbon sequestration for 250 number of trees was $488,183 \mathrm{~kg}$ carbon, which was equal to 488.183 tons carbon. Due to this volume, the analysis was extended to define the contribution of carbon reduction to a person via urban green reserve compared to the average carbon footprint for estimating the populations of a case study area. Table 3 shows the analysis and findings of carbon sequestration via urban green space in the case study area in Pasir Gudang. 
PLANNING MALAYSIA

Journal of the Malaysia Institute of Planners (2015)

Table 2. Numbers of tree and sequestration estimation at urban green reserve

\begin{tabular}{lrr}
\hline Tree Species & $\begin{array}{r}\text { Numbers of } \\
\text { tree }\end{array}$ & $\begin{array}{r}\text { Estimated Carbon } \\
\text { Sequestration } \\
\text { Per Tree (kg) }\end{array}$ \\
\hline Hevea brasiliensis (Getah) & 35 & 55,850 \\
Dyera costulata (Jelutong) & 1 & 895 \\
Khaya senegalensis (Khaya) & 16 & 72,119 \\
Syzygium grande (Jambu Laut) & 29 & 32,740 \\
Alstonia angustiloba (Pulai) & 47 & 161,329 \\
Peltophorum pterocarpum (Yellow Flame) & 22 & 18,823 \\
Pongamia pinnata (Mempari) & 10 & 8,990 \\
Mimusops elengi (Tanjung) & 7 & 8,289 \\
Garcinia mangostana (Manggis) & 2 & 877 \\
Forest Species (Kandis) & 1 & 1,211 \\
Dalbergia oliveri (Tamalan Tree) & 1 & 272 \\
Fagraea fragrans (Tembusu) & 2 & 1,488 \\
Hopea odorata (Merawan Siput Jantan) & 17 & 11,878 \\
Sandoricum koetjape (Sentul) & 2 & 5,060 \\
Samanea saman (Hujan-hujan) & 16 & 18,004 \\
Syzygium polyanthum (Salam) & 9 & 6,748 \\
Delonix regia (Semarak Api) & 1 & 729 \\
Cinnamomum iners (Kayu Manis) & 4 & 4,343 \\
Pterocarpus indicus (Angsana) & 28 & 78,538 \\
\hline Total & 250 & 488,183 \\
\hline
\end{tabular}

Table 3. Carbon sequestration via urban green space

\begin{tabular}{llr}
\hline \multicolumn{2}{c}{ Analysis } & Finding \\
\hline a. & Carbon sequestration via urban green reserve & 488.183 tons \\
b. & Estimated population within 5 meter radius of open space & 10,000 \\
c. $\quad$ Contribution of carbon reduction per person per year via & 0.049 tons (48.818kg) \\
& urban green reserve (kg or ton carbon) & 7.100 tons \\
d. $\quad$ Average carbon footprint per person per year & $71,000.000$ tons \\
e. $\quad$ Carbon sequestration for 10,000 populations & $0.690 \%$ \\
F. $\quad$ Contribution of carbon reduction per person per year via & \\
& urban green reserve compared to the average carbon \\
& footprint for 10,000 estimated populations
\end{tabular}

The information and calculation in Table 3 and the Kato's (1978) formula applied showed that the average of carbon sequestration per person per year via urban green reserve in the case study area in Pasir Gudang was 0.049 tons or $48.818 \mathrm{~kg}$. It means every single person in Pasir Gudang emits only 0.049 tons of carbon per year through the trees planted in the urban green reserve.

According to the Ministry of Natural Resources and Environment (MNRE) during the National Conference on Green Technology on 9th and 10th of June 2014, the average of carbon footprint per person per year in Malaysia in 2014 was 7.1 tons. Malaysian annual carbon footprint was smaller compared to the annual carbon footprint of average Britons (British) at 10.92 tons of carbon produced 
Alamah Misni, Sakurah Jamaluddin, \& Siti Mazwin Kamaruddin

Carbon Sequestration Through Urban Green Reserve and Open Space

each year (Ian \& Jonathan, 2006). For the purpose of this research, 7.1 tons was used as the benchmark in the calculation of carbon sequestration in the case study area. Using this parameter, this study found that the contribution of carbon reduction per person per year through carbon sequestration for estimated of 10,000 populations was only $0.69 \%$.

The findings from the quantifications remind us that this limited space has not been fully utilized for the purpose of carbon emission reduction in Pasir Gudang. Therefore, the findings can assist responsible individuals and stakeholders in justifying and recommending more programmes such as tree planting activities. In addition, the responsible authorities can recommend stronger strategies and smarter planning by consolidating low carbon initiatives to increase the contribution of carbon sequestration within this urban area. With appropriate planning, an urban green reserve will be an asset for future generations in Pasir Gudang to gain a quality environment and a healthy lifestyle.

\section{Carbon Sequestration of Open Space}

The 'Sungai Buluh' recreation site is an open space area located in the middle of the case study area and it is covered by 8.00 hectare. The primary function of this open space is to act as a sport and recreational area for the surrounding community, as well as a social interactive area, and other summit activities by the local community. This open space has been there since 1990 and has become one of the popular open spaces in Pasir Gudang area. The types of trees in the urban green reserve of Pasir Gudang have been dominated by native species and is in line with the maturity of the urban area which has started more than 20 years ago (Refer to Figure 4).

Several tree species that are quite a synonym to Pasir Gudang and can be found mostly at the urban green reserve, for instance, Pterocarpus indicus, Alstonia angustiloba, Syzygium grande, and Hevea brasiliensis. All these tree species have similar characteristics including low maintenance, high survival rate, and sustainable in various types of weather condition. This is also the main reason for the local authority to choose these tree species for landscaping purposes at the urban green reserve. The total acreage of the open space in the case study area was 8.0 hectares. For the purpose of this research, land use of open space was divided into two categories; tree planting area and non-tree planting area (Table 4). Tree planting area consisted of all areas that are covered with trees of any types regardless of the age of trees and its characteristics. 


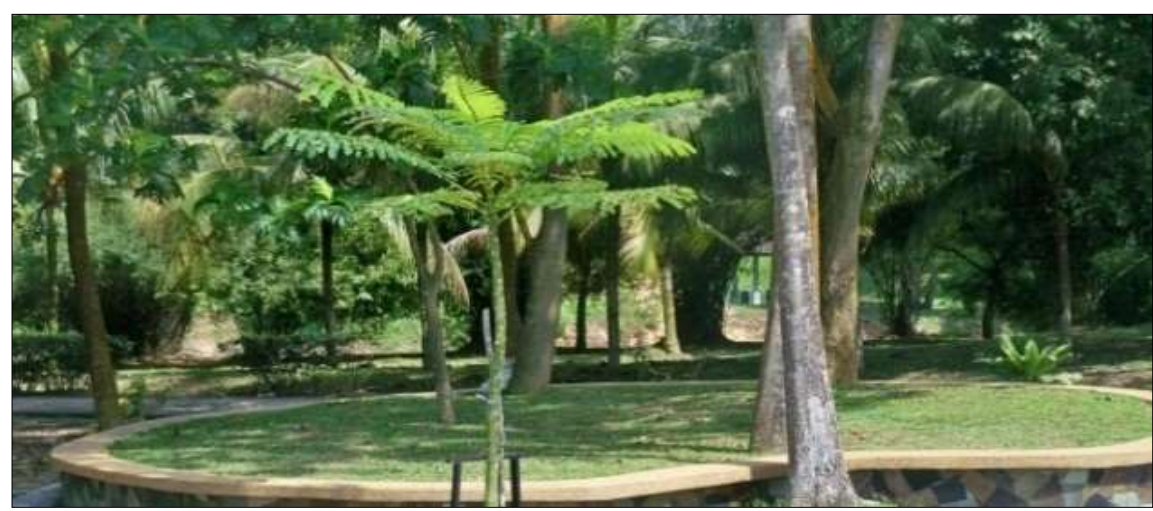

Figure 4: Current condition, and tree species planted in the park

Table 4. Estimated carbon sequestration at open space, Pasir Gudang

\begin{tabular}{lccr}
\hline Type of Open Space & $\begin{array}{c}\text { Area } \\
\text { (hectare) }\end{array}$ & Percent (\%) & $\begin{array}{r}\text { Estimated Carbon Sequestration } \\
\text { Per Hectare }\end{array}$ \\
\hline Tree Planting Area & 7.0 & 88.0 & 7.0 hectares x 250 tons \\
& & & 1,750 tons \\
Non-tree planting area & 1.0 & 12.0 & - \\
\hline Total & 8.0 & 100 & 1,750 tons \\
\hline
\end{tabular}

The acreage of the tree planting area was 7.0 hectares that covered $88.0 \%$ of the open space. However, the non-tree planting area consists of several land use activities including infrastructure (road), utility (sub-station) public facilities (toilet and praying building), playground, building, concrete structure, and a green surface planted with grass or shrub. The non-tree planting area of this open space covered $12.0 \%$ of the area, equal to 1.0 hectares. Through Kato's formula, carbon sequestration can only be counted in the area that is covered by primary trees. Other than that, it will not contribute to carbon reduction including the green surface that theoretically can only provide less than $1 \%$ of carbon sequestration.

Therefore, the exact boundary of the tree planting area is crucial to be identified because it will determine the rate of carbon sequestered by open space. Technically, based on the data tabulated, the estimated carbon sequestration for an open space of 7.0-hectare tree planting area is 1,750 tons per year. This figure means that every hectare of open space in Pasir Gudang has contributed 250 tons of above-ground biomass per year to offset carbon emission for the surrounding development. Compared to the estimated number of populations within $500 \mathrm{~m}$ radius of the open space which is 10,000 populations, the carbon sequestration of the open space absorbed 0.175 -tonne carbon per person per year or $175 \mathrm{~kg}$ (1 tonne $=1,000 \mathrm{~kg}$ ) per person per year. 
Alamah Misni, Sakurah Jamaluddin, \& Siti Mazwin Kamaruddin

Carbon Sequestration Through Urban Green Reserve and Open Space

This figure is higher than the urban green reserve because the area of open space is much bigger and the tree density is compact because clustering planting makes tree growth faster. However, through the calculation shown in Table 5, the findings indicated that the contribution of carbon sequestration from open space was $2.46 \%$. The figure considered the carbon footprint of 7.1 tons per person per year for the estimated population in the case study area of 10,000 . The tabulation showed unexpected results of actual carbon sequestration scenario in an urban area which tells us that $10 \%$ of the open space in planning requirement is in line with the requirement of carbon sequestration. The figure $2.46 \%$ (Table 5) is considered very low and it is far away from the national target of $10 \%$ carbon sequestration via tree planting. Therefore, actions need to be taken to utilize the contribution by generating high carbon sequestration in open spaces in urban areas even though we might face the biggest challenge of retrofitting the existing development.

Table 5. Carbon sequestration via open space

\begin{tabular}{llr}
\hline Analysis & Finding \\
\hline a. & Carbon sequestration via open space & 1,750 tons \\
b. & Estimated population within 5 meter radius of open \\
& space & 10,000 \\
c. $\quad$ Contribution of carbon reduction per person per year via & 0.175 tons $(175 \mathrm{~kg})$ \\
& open space (kg/ton carbon) & Average 7.1 tons \\
d. $\quad$ Carbon footprint per person per year & 71,000 tons \\
e. $\quad$ Carbon sequestration for 10,000 populations & $2.46 \%$ \\
f. $\quad$ Contribution of carbon reduction per person per year via & \\
& open space compared to average of carbon footprint for \\
& 10,000 estimated populations
\end{tabular}

\section{Total of Carbon Sequestration}

According to the analysis and findings in urban green reserve and the open space of Pasir Gudang urban area, the total of carbon sequestration was determined to portray the current scenario. Table 6 reveals that the total of carbon sequestration contributed by both urban green reserve and open space was 2,238.183 tons carbon per year. With the 10,000 estimated populations within 5-meter radius and the carbon footprint per person per year which is 7.1 tons per person per year, the total contribution of carbon reduction is $3.15 \%$ per year.

Based on the calculation, technically urban green reserve and open space in Pasir Gudang urban area generated only $3.15 \%$ of carbon sequestration, and this is very low compared to the target of $10 \%$. It means, another $6.85 \%$ carbon sequestration needs to be generated to achieve the national target of $10 \%$ carbon reduction through carbon sequestration. Considering Pasir Gudang is an old town surrounded by mature trees with a minimum age of 10 years old, a conclusion can be made that $10 \%$ of open space and urban green reserve for every development area will only contribute to $1 / 3$ of the carbon sequestration target of 
$10 \%$. Therefore, in order to achieve the $10 \%$ target, the size of the open space and urban green reserve shall increase three times the current scenario or the size of open space is $30 \%$ of the development area which have been practiced in other urban areas like Putrajaya (37.6\%) (PJCorp., 2012).

Table 6: Total carbon sequestration via urban green reserve and open space in urban

\begin{tabular}{|c|c|}
\hline Analysis & $\begin{array}{r}\text { Carbon } \\
\text { Sequestration }\end{array}$ \\
\hline Carbon sequestration via urban green reserve & 488.183 tons \\
\hline Carbon sequestration via open space & $1,750.000$ tons \\
\hline Total carbon sequestration & $2,238.183$ tons \\
\hline Estimated population within $5 \mathrm{~m}$ radius of open space & 10,000 \\
\hline Carbon sequestration per person per year & 0.224 tons \\
\hline Carbon footprint per person per year & 7.100 tons \\
\hline $\begin{array}{l}\text { Contribution of carbon reduction per person per year via urban green } \\
\text { reserve compared to the average carbon footprint for } 10,000 \\
\text { estimated populations }\end{array}$ & $0.690 \%$ \\
\hline $\begin{array}{l}\text { Contribution of carbon reduction per person per year via open space } \\
\text { compared to average of carbon footprint for } 10,000 \text { estimated } \\
\text { populations }\end{array}$ & $2.460 \%$ \\
\hline $\begin{array}{l}\text { Contribution of carbon reduction per person per year via urban green } \\
\text { reserve and open space compared to carbon footprint for } 10,000 \\
\text { populations }\end{array}$ & $3.150 \%$ \\
\hline Carbon reduction targets via carbon sequestration & $10.00 \%$ \\
\hline $\begin{array}{l}\text { The total balance of carbon reduction needs to be offset via carbon } \\
\text { sequestration }\end{array}$ & $6.85 \%$ \\
\hline
\end{tabular}

\section{Average Carbon Sequestration by Tree Species}

A tree inventory for all tree species planted along the urban green reserve has been carried out not only for the identification of total carbon sequestration but also to determine the average of carbon sequestration for every tree species per year. The average carbon sequestration for every tree species can be obtained by combining all the carbon sequestration for every mature tree species and divided by the number of trees of the same species or as shown as follows:

\section{Average carbon $=$ Total carbon sequestration for a particular tree species sequestration per Numbers of tree (same tree species)} tree species per year (for mature trees)

This data is vital for this research because it will be used as a benchmark for the rate of carbon sequestration for every particular species. In addition, it can 
Alamah Misni, Sakurah Jamaluddin, \& Siti Mazwin Kamaruddin

Carbon Sequestration Through Urban Green Reserve and Open Space

also be used to calculate and identify the future projection number of trees needed to be planted until 2025. This is done in order to achieve the $10 \%$ target of carbon sequestration via urban green reserve and open space. According to data tabulated in Table 7, currently five tree species generate the highest carbon sequestration in the urban area in Pasir Gudang. All tree species counted in this tabulation were based on the mature trees that cover the age of 10 years and above.

Table 7. Average carbon sequestration per tree per year in urban green reserve

\begin{tabular}{lrrr}
\hline Tree Species & $\begin{array}{r}\text { Numbers } \\
\text { of Tree }\end{array}$ & $\begin{array}{r}\text { Estimated } \\
\text { Carbon } \\
\text { Sequestration } \\
\text { Tree }(\mathrm{kg})\end{array}$ & $\begin{array}{r}\text { Average } \\
\text { Carbon } \\
\text { Pequestration } \\
\text { Pree (kg) }\end{array}$ \\
\hline Hevea brasiliensis (Getah) & 35 & 55,850 & 1,596 \\
Dyera costulata (Jelutong) & 1 & 895 & 895 \\
Khaya senegalensis (Khaya) & 16 & 72,119 & 4,507 \\
Syzygium grande (Jambu Laut) & 29 & 32,740 & 1,129 \\
Alstonia angustiloba (Pulai) & 47 & 161,329 & 3,433 \\
Peltophorum pterocarpum (Yellow & 22 & 18,823 & 856 \\
Flame) & & & \\
Pongamia pinnata (Mempari) & 10 & 8,990 & 899 \\
Mimusops elengi (Tanjung) & 7 & 8,289 & 1,184 \\
Garcinia mangostana (Manggis) & 2 & 877 & 438 \\
Garrcinia griffithii (Kandis) & 1 & 1,211 & 1,211 \\
Dalbergia oliveri (Tamalan Tree) & 1 & 272 & 272 \\
Fagraea fragrans (Tembusu) & 2 & 1,488 & 744 \\
Hopea odorata (Merawan Siput Jantan) & 17 & 11,878 & 699 \\
Sandoricum koetjape (Sentul) & 2 & 5,060 & 2,530 \\
Samanea saman (Hujan-hujan) & 16 & 18,004 & 1,125 \\
Syzygium polyanthum (Salam) & 9 & 6,748 & 750 \\
Delonix regia (Semarak Api) & 1 & 729 & 729 \\
Cinnamomum iners (Kayu Manis) & 4 & 4,343 & 1,111 \\
Pterocarpus indicus (Angsana) & 28 & 78,538 & 2,895 \\
\hline Average & & & 1,421 \\
\hline
\end{tabular}

These five tree species as listed below as well as other tree species that have contributed the highest carbon sequestration can be promoted in urban green reserve and open space for future planning.

i. Khaya senegalensis (Khaya) - average sequester $4,507 \mathrm{~kg}$ carbon per year.

ii. Alstonia angustiloba (Pulai) - average sequester 3,433 kg carbon per year.

iii. Pterocarpus indicus (Angsana) - average sequester 2,895kg carbon per year.

iv. Sandoricum koetjape (Sentul) - average sequester $2,530 \mathrm{~kg}$ carbon per year.

v. Hevea brasiliensis (Getah) - average sequester 1,596kg carbon per year. 
PLANNING MALAYSIA

Journal of the Malaysia Institute of Planners (2015)

\section{Estimated Number of Trees Required to Offset Carbon Footprint}

It is difficult to offset all carbon footprints per person per year through tree planting in urban green reserve and open space. However, it is good to give some indication to the local authority and public on how many number of trees needed for every single person to offset their own carbon footprint per year. With this information, every single person will feel responsible for reducing their own carbon footprint by planting trees. Below is the formula to calculate the estimated number of trees needed to offset carbon footprint per person per year.

Estimated number of tree $=$ Average carbon footprint per person per year needed to offset carbon $\quad$ Average carbon sequestration per tree per year

footprint per person per year

Table 8 shows that technically, every single person living in urban areas of Pasir Gudang needs five number of trees to offset or to absorb and store their individual carbon footprint generated through daily activity. On the other hand, every household needs to plant five number of trees in order to reduce the carbon emission to zero.

Table 8. Estimated numbers of trees needed to offset carbon footprint per person per year

\begin{tabular}{lc}
\hline \multicolumn{1}{c}{ Analysis } & Findings \\
\hline Average carbon footprint per person per year & 7.100 tons \\
Average carbon sequestration per tree per year & 1.421 tons \\
Estimated numbers of tree needed to offset carbon & 5 trees \\
footprint per person per year & \\
\hline
\end{tabular}

In a case study in Pasir Gudang, the carbon sequestration via urban green reserve and open space only contributed less than 5\% and is still far from achieving the $10 \%$ target of carbon reduction through carbon sequestration (IRDA 2012). However, this not the reason to stop implementing green and low carbon initiatives in planning and developing green space, but it is a challenge to improve the ordinary approach to a better urban green reserve and open space towards high carbon sequestration. Through smart planning of urban green reserve and open space, the utilization of the function of these two limited areas will be more efficient to act as a carbon sink of the urban area. The most important factor is to plan an appropriate and implementable method of carbon sequestration for the local authority. Therefore, we have to identify the best practice of integrated urban development towards green and low carbon development by adopting related and significant initiative for every type of development. 
Alamah Misni, Sakurah Jamaluddin, \& Siti Mazwin Kamaruddin

Carbon Sequestration Through Urban Green Reserve and Open Space

\section{CONCLUSION}

The results revealed that technically, carbon sequestration generated by trees at the urban green reserve and open space in Pasir Gudang urban area was only $3.15 \%$, and this figure is small compared to the $10 \%$ national target. Therefore, to achieve the $10 \%$ carbon sequestration, the size of open space and the number of trees in urban green reserve must be three times the current size. In other words, the area of open space and urban green reserve must be more than $30 \%$ of the development area. However, for existing urban area like Pasir Gudang, there is not enough space to add another open space unless some existing development is converted to become a carbon sink. Therefore, retrofitting the existing urban green reserve and open space is the most significant way to create a carbon sink through smart planning and choosing the appropriate tree species that contribute to high carbon sequestration. In line with the green development and low carbon development, carbon sequestration baseline study must be conducted in every urban area in order determine the current amount of carbon sequestrated. This is a very important factor because the current contribution will help to prepare the appropriate planning and landscaping design for generating and managing carbon sequestration in an urban area, so that the $10 \%$ target of carbon sequestration can be achieved. This research attempted to orient the way forward regarding the intervention between planning and landscape perspective for enhancing a better quality of life. 


\section{REFERENCES}

Bellassen, V. \& Sebastiaan, L. (2014). Carbon Sequestration: Managing Forest in Uncertain Times. Retrieved from http:/www.nature.com/news/carbonsequestration-managing-forest.

COP15. (2009). Copenhagen Climate Change Conference. Retrieved from http://unfccc.int/meetings/copenhagen_dec_2009/meeting/6295.php.

Dhakal, S. (2009). Urban energy use and carbon emissions from cities in China and policy implications, Energy Policy (37), 4208-4219.

EIA (Energy Information Administration). (2006). Energy-related Emissions Data \& Environmental Analyses. Http://www.eia.doe.gov/environment.html.

EPA (Environmental Protection Agency). (2014). Carbon Pollution Standards. Retrieved from http://www.c2es.org/federal/executive/epa/carbon-pollutionstandards-power-plants?gclid=CIfm7O_348QCFREmjgodtpgAxw.

Hamburg, S.P., Harris, N., Jaeger, J., Karl, T.R., McFarland, M., Mitchell, J.F.B., Oppenheimer, M. S., Santer, Schneider, S., Trenberth, K.E. \& Wigley, T.M.L. (1997). Common questions about climate change, United Nation Environment Programme: World Meteorology Organization, USA.

Houghton, J.T., Meira F.L.G., Callender, B.A., Harris, N., Kattenberg, A. \& Maskell, K., (Eds.). (1996). Climate Change 1995: The Science of Climate Change. Cambridge: USA.

Ian, H. \& Jonathan, B. (2006). Your Carbon Footprint Revealed: Climate Change Reports Find We Each Produce 11 Tons of Carbon A Year. Retrieved from http:/www.independent.co.uk/environment/climate-change/yourcarbonfootprint-revealed.

IRDA. (2012). Low Carbon Society Blueprint for Iskandar Malasyia 2025. Universiti Teknologi Malaysia 2025, Iskandar Regional Development Authority, Kyoto University, Okoyama University \& National Institute for Environment Studies.

Kato, R., Tadaki, Y. \& Ogawa, H. (1978). Plant biomass and growth increment studies in Pasoh Forest. Malayan Nature Journal.

Kato, H. (2011). Climate Change, Carbon Sequestration, and the Law of the Sea. United Nation University, Yokohama, Japan.

KeTTHA, (2014). Ministry of Energy, Green and Water. Retrieved from http://www.kettha.gov.my.

Kueh J.H.R., Majid, N.M. Seca, A. G. \& Ahmed, O.H. (2013). Above Ground Biomasscarbon Partitioning, Storage and Sequestration in a Rehabilitated Forest, Bintulu, Sarawak, Malaysia. Sains Malaysiana, 42 (8), 1041-1050.

Pasir Gudang Local Authority (2008). Pasir Gudang Local Plan 2020.

Misni, A. (2012). The Effects of Surrounding Vegetation, Building Construction and Human Factors on the Thermal Performance of Housing in a Tropical Environment. PhD Thesis, Victoria University of Wellington, New Zealand.

Misni, A. \& Allan, P. (2010). Sustainable residential building issues in urban heat islands-the potential of albedo and vegetation. Proceeding in Sustainable Building New Zealand Conference (SB10).

Myers, N. \& Goreau, T. J. (1991). Tropical Forests and the Greenhouse Effect: A Management Response. Discovery Bay Marine Laboratory, University of the West Indies, Discovery Bay, Jamaica. 
Alamah Misni, Sakurah Jamaluddin, \& Siti Mazwin Kamaruddin

Carbon Sequestration Through Urban Green Reserve and Open Space

NASA, (2014). Global climate change. Retrieved from http://climate.nasa.gov/evidence/. Nowak, D.J. \& Crane, D.E. (2002). Carbon storage and sequestration by urban trees in the USA. Environmental Pollution, 116, 381-389.

Nowak, D. J., Eric, J., Greenfield, Hoehn, R. E. \& Lapoint, E. (2013). Carbon storage and sequestration by trees in urban and community areas of the United States. Environmental Pollution, 178, 229-236.

Olivier, J., Van, A. J., Dentener, F., Pagliari, V., Ganzeveld, L. \& Peters, J. (2005). Recent trends in global greenhouse gas emissions: Regional trends 1970-2000 and spatial distribution of key sources in 2000. Environmental Sciences, 2, 81-99.

PJCorp. (2012). Laporan Inisiatif Bandar Hijau Karbon Rendah Bandar Hijau Karbon Rendah Putrajaya.

Sedjo, R.A. (1989). Forests to offset the greenhouse effect, Journal of Forestry, 87, 12 15.

The Commissioner of Law Revision Malaysia (2006). Town and Country Planning Act 1976 (Act 172).

UNEP. (2014). Carbon Management in Natural Ecosystem. Grid Arendal, A Centre Collaborating with UNEP. Retrieved http:/www.grinda.no/publications/rr/natural-fix/page/3725.aspx.htm.

UNFCC. (2011). The UNFCCC and the Kyoto Protocol. Network of Regional Governments for Sustainable Development.

Unwin G.L. \& Kriedemann P.E. (2000). Principles and Process of Carbon Sequestration by Trees. Research and Development Division State Forest of New South Wales, Sydney.

USDA (United States Separtment of Agriculture). (2014). Open Space Conservation. Retrieved from http://www.fs.fed.us/openspace/faq.html\#n1

Weng, Q. and Yang, S., (2006). Urban air pollution patterns, land use, and thermal landscape: An examination of the linkage using GIS. Environmental Monitoring and Assessment, 117, 463-489. 